\title{
Late-Holocene Atlantic bottom-water variability in Igaliku Fjord, South Greenland, reconstructed from foraminifera faunas
}

\author{
Susanne J. Lassen, ${ }^{1 *}$ Antoon Kuijpers, ${ }^{1}$ Helmar Kunzendorf, ${ }^{2}$ \\ Gerd Hoffmann-Wieck, ${ }^{3}$ Naja Mikkelsen ${ }^{1}$ and Peter Konradi ${ }^{1}$
}

\author{
$\left({ }^{1}\right.$ Geological Survey of Denmark and Greenland, Østervoldgade 10, DK-1350 \\ Copenhagen K, Denmark; ${ }^{2}$ Geographic Institute, University of Copenhagen, \\ Østervoldgade 10, DK-1350 Copenhagen K, Denmark; ${ }^{3}$ GEOMAR Research \\ Center for Marine Geosciences, Wischhofstrasse 1-3, D-24148 Kiel, Germany)
}

Received 22 April 2002; revised manuscript accepted 18 December 2002

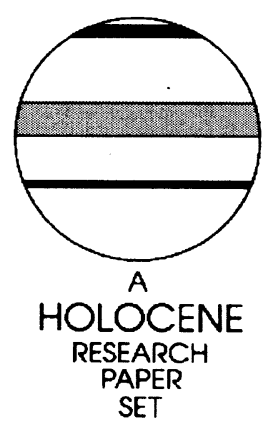

SET

\begin{abstract}
A high-resolution record of late-Holocene subsurface water-mass characteristics in outer Igaliku Fjord, South Greenland, is presented based on benthic foraminifera faunas from core PO 243-451 collected from a water depth of $304 \mathrm{~m}$. Stratification with Atlantic water masses present in the lower part of the watercolumn is suggested to have prevailed during the last $3200 \mathrm{cal}$. years, except for a period referred to as the 'Mediaeval Warm Period' (MWP). During the MWP (c. AD 885-1235) the outer part of Igaliku Fjord experienced enhanced vertical mixing and a high hydrodynamic energy level which we ascribe to increasing wind stress through this period, corresponding to the period of the Norse settlement. The transition from the MWP to the 'Little Ice Age' (LIA) shows a two-step pattern with a short climatic amelioration around AD 1520 before maximum cooling occurred. The intensified wind stress and the overall environmental change are suggested to have contributed to the loss of the Norse settlement in Greenland. Periods with strong stratification and marked influence of Atlantic subsurface water masses around 2.6, $1.3 \mathrm{ka} \mathrm{BP}$ and during the LIA are correlated to North Atlantic Holocene ice-rafting events reported by Bond et al. (1997).
\end{abstract}

Key words: Benthic foraminifera, palaeoceanography, hydrography, climatic change, Atlantic bottom water, ocean currents, Greenland, Norse settlement, late Holocene, 'Little Ice Age', 'Mediaeval Warm Period'.

\section{Introduction}

Evidence is mounting that the North Atlantic did not only experience millennial-scale climatic variability during glacial times (DansgaardOeschgaard events; Bond et al., 1993), but also during interglacial times, though the variations were less pronounced (e.g., O'Brian et al., 1995; Bianchi and McCave, 1999; Bond et al., 1997; 2001). The average pacing of the climatic changes during the Holocene is around 1500 years (Bond et al., 1997; Bianchi and McCave, 1999; Arz et al., 2001), but a variety of shorter periodicities with a series of spectral peaks ranging from 69 to 1046 years have also been noted (Hong et al., 2000). A more recent example, and in some areas the most pronounced, of these climatic changes is the 'Mediaeval Warm Period' (MWP) to the 'Little Ice Age' (LIA) oscillation. The forcing causing these climatic oscillations is still an unsolved puzzle, but

*Author for correspondence (e-mail: sl@geus.dk) the solar activity together with the ocean thermohaline circulation is considered to have played an important role (Bond et al., 1997; 2001; Broecker, 2000).

The impacts of these natural climatic changes on mankind have been considerable. For instance, on Iceland widespread farming was rare before $\mathrm{AD} 1280$, but after that time this happened frequently (Finsson, 1970). Thus, the Norse, under Eric the Red, were able to colonize South Greenland at AD 985, according to the Icelandic Sagas, owing to the mild MWP climate with favourable open-ocean conditions. This is close to the peak of Mediaeval warming recorded in the GISP2 ice core which was dated at AD 975 (Stuiver et al., 1995). Their disappearance coincides with the onset of the LIA, but the timing of the ultimate loss of the Norse settlement in South Greenland ('Eastern Settlement') has not yet been determined. Studies of a Canadian high-Arctic ice core and nearby geothermal data (Koerner and Fisher, 1990) correspondingly show a significant temperature lowering at $\mathrm{AD} 1350-1400$. This corresponds to the period 
when the Norse society in Greenland was declining and reaching its final stage probably before the end of the fifteenth century.

To improve our knowledge on the local marine processes and conditions during this final settlement stage, and compare these with hydrographic and climatic variability during the last millennia of the Holocene, we focused on the outer part of Igaliku Fjord, South Greenland. This area is part of the Eastern Settlement where the ruins and remains from the first European settlers on Greenland are concentrated, and at the same time well exposed to openocean influences, which implies that large-scale ocean-circulation changes may also be recorded. For this purpose, namely to reconstruct the hydrographic development of this outer part of Igaliku Fjord and establish possible links with the large-scale climate events involved, a multiproxy approach has been applied. The various parameters analysed and discussed below include benthic foraminiferal faunas, stable isotopes and magnetic susceptibility. In addition, analysis of diatom floras and palynofacies have been carried out on this core as well and published by Jensen $e$ t al. (2004) and Roncaglia and Kuijpers (2004), respectively.

\section{Environmental setting}

The entrance of Igaliku Fjord is formed by an $11 \mathrm{~km}$ long narrow sea inlet at the southwestern Greenland coast. There is no threshold and the fjord floor generally deepens offshore continuing as a narrow channel across the shelf. The maximum water depth in the outer Igaliku Fjord is around $475 \mathrm{~m}$.

The modern hydrography in this area is characterized by two water masses. The (sub)polar cold, low-salinity surface waters originate from the East Greenland Current (EGC), which turns north around Cape Farewell and continues along the (south)west coast of Greenland as the West Greenland Current. Below these cold surface water masses, and outcropping at the surface further offshore, relatively warm (up to $c .4^{\circ} \mathrm{C}$ ) and saline Atlantic water is found (Horsted, 1956; Buch, 2000). West of Cape Farewell increasing mixing between these two water masses occurs, but they can still be separated in our study area. Thus, the upper part of the water-column in the outer Igaliku Fjord derives from the EGC, whereas at greater subsurface depth $(>200 \mathrm{~m})$ Atlantic water advected by the Irminger Current is present. A normal seasonal trend shows increasing influence of Atlantic water masses in late summer and early autumn, whereas EGC water masses are dominant earlier in the year.

Previous studies of benthic foraminifera in fjords of Greenland have been carried out on recent sediments (e.g., Madsen and Knudsen, 1994; Jennings and Helgadottir, 1994), and occasionally also on sediment cores for palaeoenvironmental reconstruction (e.g., Jennings and Weiner, 1996; Jennings et al., 2002). In the fjords of our study region very limited palaeoenvironmental work has so far been done (Herman et al., 1972). The latter study dealt with benthic foraminifera from cores from the central Igaliku fjord. However, the stratigraphic control in this investigation is very poorly constrained due to a lack of ${ }^{14} \mathrm{C}$ dates.

\section{Foraminiferal assemblages, ecology and water-mass characteristics}

The calcareous species Cassidulina neoteretis is typical in the modern environments of the East Greenland shelf and found associated with Atlantic intermediate water masses (Jennings and Helgadottir, 1994). This species is also found in the chilled Atlantic water masses north of Norway in the Barents Sea (Steinsund, 1994).

The two Arctic species Elphidium excavatum and Cassidulina reniforme are also represented in these areas, but they are more specifically associated with lower temperature and salinity in areas close to ice margins (Steinsund, 1994; Hald et al., 1994; Jennings and Helgadottir, 1994). A suite of taxa, such as Astrononion gallowayi, Cibicides spp. and Triferina angulosa, occur in recent sediments characterized by a coarse substrate and a high-energy hydrodynamic environment (Sejrup et al., 1984; Mackensen, 1987; Steinsund, 1994).

Areas in the proximity of the oceanic polar front show high abundance of, for example, Nonionellina labradorica (see Steinsund, 1994) and Islandiella norcrossi (see Hald and Steinsund, 1992), while the distribution of Melonis barleeanus is mainly controlled by the presence of partly decomposed organic material (Caralp, 1989).

\section{Materials and methods}

Core PO $245-451$ is $351 \mathrm{~cm}$ long and was collected in 1998 by $\mathrm{R} / \mathrm{V}$ Poseidon (Hoffmann et al., 1999). The water depth at this site $\left(60^{\circ} 41.96^{\prime} \mathrm{N}, 46^{\circ} 02.00^{\prime} \mathrm{W}\right)$ at the entrance of Igaliku Fjord close to Qaqortoq/Julianehaab is $304 \mathrm{~m}$ (Figure 1). The sediment in the lower part of the core consists of homogeneous grey silty clay. Between 131 and $93 \mathrm{~cm}$ the sediment consists mainly of sandy silt. The upper part of the core is olive-grey silt with isolated black specks. The core was subsampled at $5 \mathrm{~cm}$ intervals between 120 and $90 \mathrm{~cm}$ core depth and at $3 \mathrm{~cm}$ intervals in the remaining upper part. No samples were analysed from below $120 \mathrm{~cm}$ core depth.

For foraminiferal analysis the samples were dried, weighted and washed through sieves with mesh sizes 0.1 and $1.0 \mathrm{~mm}$. Then the fractions were dried and weighted. Foraminifera were counted from the $0.1 \mathrm{~mm}$ fraction. Three hundred individuals were counted in each sample, if possible (a table showing the complete percentage distribution of benthic foraminifera in core PO 243-451

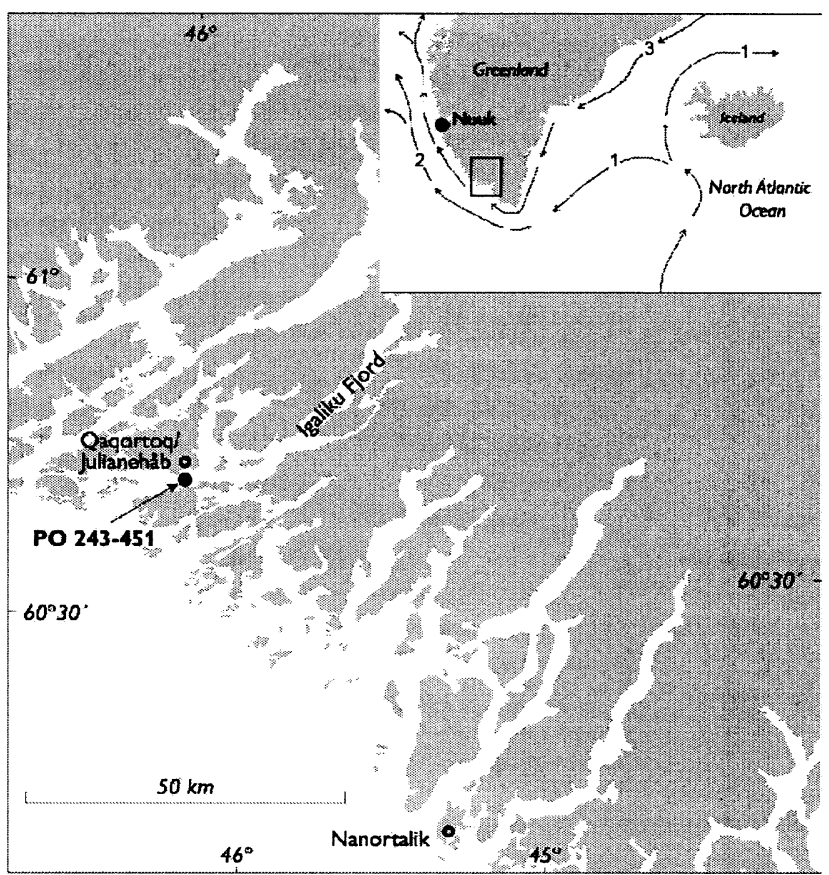

Figure 1 Map of the study area with indication of the position of core PO 245-451 in the outer Igaliku Fjord. The inset map displays the regional setting of the study area and the general ocean circulation pattern. (1) The Irminger Current is a branch of the warm North Atlantic Current and flows west of Iceland as well as south following the east coast of Greenland turns north around Cape Farewell and continues northward as the West Greenland Current (2). (3) The cold iceberg-loaded East Greenland Current (EGC). The Greenland inland ice is not illustrated on this figure. 
is available online at http://www.arnoldpublishers.couk/journals/ pages/holocene/data.htm).

Oxygen isotope ratios of the benthic species Cassidulina neoteretis were measured on a Finnigan MAT 252 mass spectrometer at Woods Hole Oceanographic Institute (WHOI). Given values are calibrated to the PDB scale. The total reproducibility amounts to $0.07 \%$ o for $\delta^{18} \mathrm{O}$.

The magnetic susceptibility measurements of core PO 243-451 were carried out with a hand-held Bartington magnetic susceptibility meter (MS2E1 probe) on the split core.

For stratigraphic control AMS ${ }^{14} \mathrm{C}$ dates were determined using various types of material, i.e., shell fragments, foraminifera and plant material (Table 1). In addition, non-destructive low-energy gamma-spectrometric measurements of ${ }^{210} \mathrm{~Pb}$ and ${ }^{37} \mathrm{Cs}$ activities (for methods and results, see Kunzendorf et al., 1998) were made on core PO $243-451$ for determining recent (last 150 years) sediment-accumulation rates. These measurements where carried out at the Risø National Laboratory, Denmark.

\section{Results}

\section{Chronology}

The ${ }^{210} \mathrm{~Pb}$ measurements document that the surface sediments are recent and the age model of core PO $243-451$ is based accordingly on a compilation of the ${ }^{14} \mathrm{C}$ dates and the ${ }^{210} \mathrm{~Pb}$ dates (Table 1), assuming constant sedimentation rates between the dated levels as shown in Figure 2. Two dates are omitted from the age model. At $57 \mathrm{~cm}$ core depth, two dates have been carried out on shell and plant material, respectively. The results of these two dates are only $70{ }^{14} \mathrm{C}$ years apart. Taking uncertainties in the measurements as well as the reservoir age into account allows us to consider the results as to yield an identical age. The age determined for the shell has been chosen for the age model. Furthermore, the age found for terrestrial plant material sampled from 99 $\mathrm{cm}$ core depth is only $20{ }^{14} \mathrm{C}$ years older than the age found for marine shell material collected from $90 \mathrm{~cm}$ core depth. Also, in this case, we gave priority to the measurement made on the shell material. We are aware that the older part of the age model might be erroneous. This, however, has hardly any relevance for the interpretations and conclusions of this paper. All the AMS ${ }^{14} \mathrm{C}$ dates have been corrected for a reservoir age of 400 years and calibrated. Within this context, it should be noted that the dated material originates from a bottom-water environment characterized by the presence of Atlantic water. The ages used in this

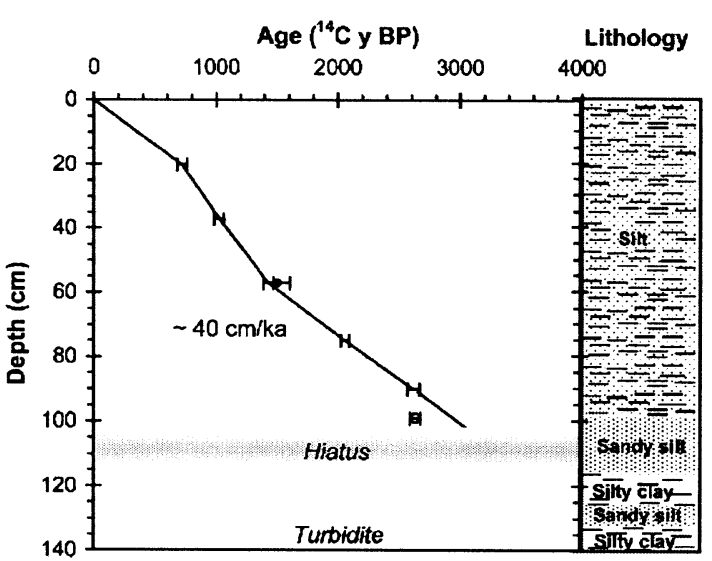

Figure 2 The age model for the upper $105 \mathrm{~cm}$ is based on the dates given in Table $1 .{ }^{14} \mathrm{C}$ ages are presented together with the average sedimentation rate $(\mathrm{cm} / \mathrm{ka}$, in calibrated years), when assuming constant sedimentation rates between the dated levels. The inferred hiatus separating the sandy sediment from the undisturbed upper section are marked with horizontal shading. In addition, the lithological column for the core is shown.

paper are calendar years unless otherwise indicated. Sedimentation rates in the upper metre are around $40 \mathrm{~cm} / \mathrm{ka}$ in average.

Between 131 and $93 \mathrm{~cm}$ core depth the sediment is more sandy except for the interval between 122 and $116 \mathrm{~cm}$, which consists of homogenous silty clay. The relative sharp lithological boundary to the silty sediment above may reflect either a hiatus or a period with very low sedimentation rates due to the AMS ${ }^{14} \mathrm{C}$ dates at 7910 and $8175{ }^{14} \mathrm{C}$ years BP from the sandy interval. Below 131 $\mathrm{cm}$ core depth the homogeneous sediment is interpreted as a turbiditic deposit. For the purpose of this paper, only the upper 105 $\mathrm{cm}$ of the core is used for reconstructing the palaeohydrographic history of the fjord. The $105 \mathrm{~cm}$ core depth is defined due to a marked change in the foraminifer fauna and not exactly at the lithological change.

\section{Foraminifera, magnetic susceptibility and oxygen isotopes}

A total of 53 different benthic foraminifera species has been determined through the analysed core section, of which only approximately eight (calcareous) species comprise $80-90 \%$ of the fauna. A selection of the most important species is shown in Figure 3. Through the investigated time interval $C$. neoteretis, C. reniforme, T. angulosa, A. gallowayi and Islandiella norcrossi/

Table $1 \mathrm{~Pb}^{219} \mathrm{Cs}^{137}$ and AMS ${ }^{14} \mathrm{C}$ dates from core PO $253-451$ and corresponding calibrated years, and for the upper part also calendar years (the ${ }^{14} \mathrm{C}$ ages are calibrated by use of the program Calib 4.0)

\begin{tabular}{|c|c|c|c|c|c|c|c|c|}
\hline $\begin{array}{l}\text { Depth } \\
(\mathrm{cm})\end{array}$ & $\begin{array}{l}\mathrm{Pb}^{219} / \mathrm{Cs}^{137} \\
(\mathrm{AD})\end{array}$ & $\begin{array}{l}\text { AAR-lab. } \\
\text { number }\end{array}$ & $\begin{array}{l}{ }^{14} \mathrm{C} \text { age } \\
\text { (uncorrected) }\end{array}$ & $\begin{array}{l}{ }^{14} \mathrm{C} \text { age (reservoir } \\
\text { corrected (400 yearś)) }\end{array}$ & $\begin{array}{l}\text { Error } \\
\text { bars }\end{array}$ & $\begin{array}{l}\text { Average calibrated } \\
\text { years BP }\end{array}$ & $\begin{array}{l}\text { Average calendar } \\
\text { years } A D\end{array}$ & Dated material \\
\hline 0 & 1995 & & & & & & & \\
\hline 2 & 1983 & & & & & & & \\
\hline 3 & 1961 & & & & & & & \\
\hline 4 & 1924 & & & & & & & \\
\hline 5 & AD 1875 & & & & & & & \\
\hline 20 & & AAR-5937 & 1120 & 720 & 40 & 665 & 1285 & plant \\
\hline 37 & & AAR-5938 & 1425 & 1025 & 40 & 935 & 1015 & shell \\
\hline 57 & & AAR-5939-2 & 1830 & 1430 & 40 & 1310 & 640 & shell \\
\hline 57 & & AAR-5959-1 & 1900 & 1500 & 110 & 1370 & 580 & plant \\
\hline 75 & & AAR-5940 & 2460 & 2060 & 35 & 2000 & - & shell \\
\hline 90 & & AAR-5468 & 3020 & 2620 & 50 & 2750 & - & forams \\
\hline 99 & & AAR-5046 & 3035 & 2635 & 45 & 2755 & - & plant \\
\hline 125 & & AAR-4990 & 8310 & 7910 & 70 & 8675 & - & shell \\
\hline 126 & & AAR-5047 & 8575 & 8175 & 65 & 9135 & - & shell \\
\hline
\end{tabular}




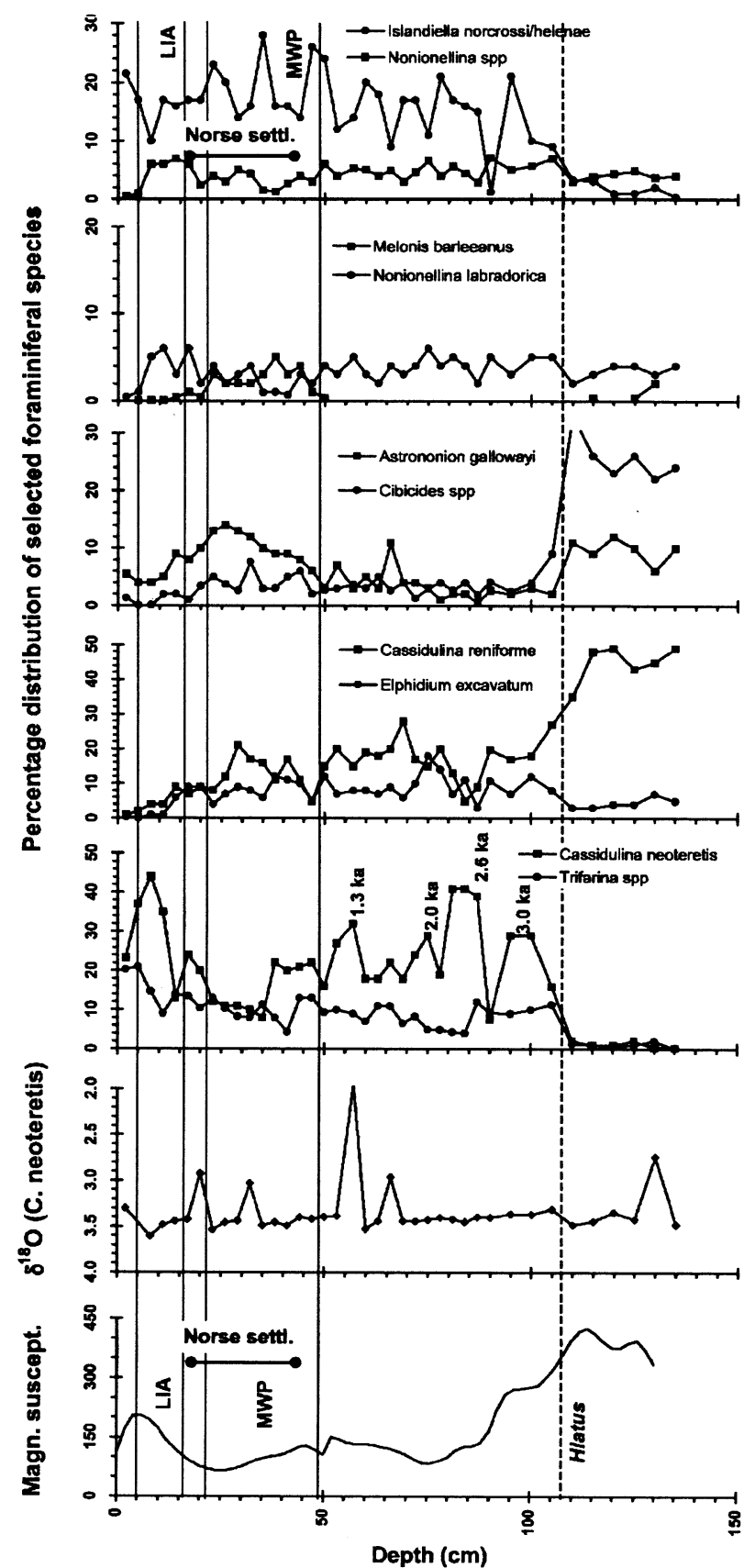

Figure 3 The relative abundance of the most important benthic foraminifera species in core PO 243-451 are shown together with the magnetic susceptibility profile and the stable oxygen isotope record. The horizontal lines indicate the position of the 'Mediaeval Warm Period' (MWP) and 'Little Ice Age' (LIA). In addition, the vertical line indicates the duration of the Norse settlement. The inferred hiatus around $105 \mathrm{~cm}$ core depth is indicated by the dotted horizontal line. The calibrated age of the peaks in relative abundance of Cassidulina neoteretis is shown $(1.3,2.6$ and 3.0 calibrated years BP).

helenae are the main constituents of the benthic fauna (in this study, the two species Islandiella norcrossi and Islandiella helenae have not been separated). The relative abundance of each of the individual species changes, however, through the interval. Thus, above the lithological boundary at $93 \mathrm{~cm}$ core depth (i.e., $2.76 \mathrm{ka} \mathrm{BP}) C$. neoteretis dominates the fauna up to $38 \mathrm{~cm}$ (i.e., $A D$ 1015), with peak values at $87-81 \mathrm{~cm}$ (i.e., 2.6-2.3 ka BP) and 57-53 cm (i.e., 1.3-1.2 ka BP/AD 640-715). Increasing abundance of $A$. gallowayi between 44 and $23 \mathrm{~cm}$ core depth (i.e., AD 8841237) follows the high abundance of $C$. neoteretis. Characteristic for this interval is also the increased occurrence of M. barleeanus.
Hereafter the abundance of $C$. neoteretis increases again and peaks in the upper part of the core (11-5 cm, i.e., AD 1640-1875). Also Bucella frigida and $N$. labradorica peaks during this period. Several species reveal a general relative decrease after the interval with the appearance of $M$. barleeanus, such as A. gallowayi, $C$. reniforme and $E$. excavatum.

The magnetic susceptibility shows a low-frequency fluctuating pattern with high values around the transition to the $M$. barleeanus interval and again in the upper part of the core. Note the striking correlation between the magnetic susceptibility and percentage of C. neoteretis apparent in the upper metre of the core.

Throughout the studied interval the oxygen isotope ratio reveals rather constant values around 3.5\%o with four levels of welldefined excursions towards lighter isotope values at $66,57,32$ and $20 \mathrm{~cm}$ core depth.

\section{Palaeohydrographic interpretation and discussion}

The sediment interval below the sample at $105 \mathrm{~cm}$ core depth is interpreted as resulting from a different environment separated from the above section by a hiatus. This is based both on the change in lithology as well as the change in the benthic foraminiferal fauna. Though no stratigraphic interpretation can be made, a hint of the original depositional environment may be found. The benthic foraminifera fauna is comprised of species like Cibicides spp., $A$. gallowayi and $C$. reniforme. The first two are epifaunal (Murray, 1991) and found in areas with a coarse-grained substrate which often reflects a high-energy hydrodynamic environment with strong bottom currents. Being epifaunal, these species are considered more robust to unstable and fluctuating food supply and thus the depositional environment for the fauna represented in this part of the core may be characterized by marked changes in water-mass properties and associated with an intermittent food supply. This is confirmed by the high dominance of $C$. reniforme which is typical in glaciomarine environments (e.g., Hald and Korsun, 1997). A glacial proximal environment could explain the coarser grain sizes and unstable hydrographic conditions with fluctuating meltwater fluxes as well as food supply. Hence, this fauna may represent an earlier-Holocene depositional environment with glacial proximity to the core site.

Through the past $c .3200$ years BP (i.e., the upper $100 \mathrm{~cm}$ ) the benthic foraminiferal fauna suggests that Atlantic water masses prevailed at the sea floor, i.e., in the lower part of the watercolumn. This is particularly evident from the presence of $C$. neoteretis, with the strongest influence of Atlantic water at 100-95 cm (i.e., 3.2-2.8 ka BP), $87-81 \mathrm{~cm}$ (i.e., $2.6-2.3 \mathrm{ka} \mathrm{BP}$ ), $57 \mathrm{~cm}$ (i.e., $1.3 \mathrm{ka} \mathrm{BP}$ ) and $11-5 \mathrm{~cm}$ (i.e., AD 1640-1875). These episodes are roughly coeval with periods of cooling recorded in the North Atlantic surface waters during intensive drift of icebergs (Holocene IRD events 2-1; Bond et al., 1997). Lower surface water temperatures are shown to correlate with the solar activity favouring a strengthening of winds from northerly direction over the North Atlantic (Bond et al., 2001; Table 2).

As also shown by the LIA sea-ice index for Iceland (Ogilvie, 1992), more widespread ice drift and stronger northerly winds indicate an intensified EGC transport of low-salinity, cold surface waters towards South Greenland. Thus, a more pronounced halocline would contribute to less mixing and better isolation of the Atlantic bottom-water masses in the outer Igaliku Fjord. Markedly enhanced advection of EGC water masses is clearly documented in the diatom record of core PO 243-443 taken in the innermost part of Igaliku Fjord (Jensen et al., 2004). Furthermore, a generally intensified EGC may simultaneously favour stronger entrainment of subsurface Atlantic water originating from the Irminger Current. Thus, the warm Atlantic signal at the bottom 
Table 2 The environmental episodes found in core PO 243-451 listed together with corresponding events known from the literature

\begin{tabular}{|c|c|}
\hline Environmental episodes & Corresponding events \\
\hline $\begin{array}{l}3.2-2.8 \mathrm{ka} \text { BP: stratification in } \\
\text { the water-column/cooling } \\
2.6-2.3 \mathrm{ka} \text { BP: stratification in } \\
\text { the water-column/cooling }\end{array}$ & $\begin{array}{l}\text { Cooling in the North Atlantic, Bond } \\
\text { event } 2(2.8-2.7 \mathrm{ka} \text { BP) (Bond et al., } \\
\text { 1997) }\end{array}$ \\
\hline $\begin{array}{l}2.0 \mathrm{ka} \text { BP: stratification in the } \\
\text { water-column/cooling }\end{array}$ & $\begin{array}{l}\text { - Cooling the Greenland ice cap (Dahl- } \\
\text { Jensen } \text { et al., 1998) } \\
\text { - Glacial advance on Iceland (Stötter } \\
\text { et al., 1999) } \\
\text { - Cooling on the Iceland shelf } \\
\text { (Eiriksson et al., 2000; Jiang et al., } \\
\text { 2002) } \\
\text { - Minor cooling in the North Atlantic } \\
\text { (Bond et al., 1997) }\end{array}$ \\
\hline
\end{tabular}

$1.3 \mathrm{ka}$ BP: stratification in the water-column/cooling

Cooling in the North Atlantic, Bond event 1 (1.4 ka BP) (Bond et al., 1997)

1070-75 yr BP ('Mediaeval Warm Period'): vertical mixing of the water-column, increasing wind activity

- Reduction of seasonal ice cover in Igaliku Fjord (Roncaglia and Kuijpers, 2004)

- Stable and warm conditions on the Greenland East Coast (Jennings and Weiner, 1996)

- Increased erosion and deposition of aeolian sediments on land around the fjord (Vebæk, 1992)

- Large-scale change in wind regime in Eastern Canada (Kasper and Allard, 2001)

AD 1405: culmination of the first - Cooling signal on the East Greenland cooling after the 'Mediaeval Warm Period' coast (Jennings and Weiner, 1996)

- Cooling in the Canadian high Arctic (Koerner and Fischer, 1990)

AD 1520: short climatic amelioration

Same pattern on the Greenland East Coast (Jennings and Weiner, 1996)

during these cold periods is interpreted as a result of a strongly stratified water-column. Within this context it is noteworthy that also in the open northwestern North Atlantic off Nova Scotia subsurface warming has been found during the LIA from the sixteenth to the nineteenth centuries (Keigwin and Pickart, 1999).

Also around $2.0 \mathrm{ka} \mathrm{BP}$ (at $75 \mathrm{~cm}$ core depth) the fauna suggests an increased influx of Atlantic subsurface water masses. This corresponds to a period of minimum borehole temperatures recorded on the Greenland ice cap (Dahl-Jensen et al., 1998; Johnsen et al., 2001). In the Atlantic records only a minor cooling is recorded (Bond et al., 2001), but on northern Iceland a glacier advance has been reported (Stötter et al., 1999) as well as cooling on the north Iceland shelf (Eiriksson et al., 2000; Jiang et al., 2002). The solar activity does not seem to have decreased at this time (Bereference; Bond et al., 2001). However, probably not all the Holocene climate events are exclusively caused by solar forcing, as, for instance, the meltwater event leading to the Preboreal cooling (Hald and Hagen, 1998). Meltwater influence could also have played a role around $2.0 \mathrm{ka}$, since the dinoflagellates suggest a salinity decrease (Roncaglia and Kuijpers, 2004). The latter information may, however, also point to temporarily increased advection of low-salinity (ice-loaded) EGC water masses. The glacier advances on Iceland (Stötter et al., 1999) also point to the possibility of a regionally lowered sea-surface temperature, possibly in combination with increased precipitation rates. In between the intervals with Atlantic water and a marked stratification, the fauna distribution shows an increased abundance of E. excavatum and
C. reniforme. These species possibly suggest lower bottom-water temperatures and a less stable hydrographic environment.

The light isotopic excursions occur mainly after $1655 \mathrm{BP}$ (AD 295) and correspond to findings on the East Greenland shelf (Jennings et al., 2001). Jennings et al. (2001) argue that this signal is caused by an overall freshening in the Atlantic intermediate water masses due to increased mixing between AIW and the polar water mass (PW) rather than increased temperature. As an alternative possibility they mention in situ sea-ice formation that could produce brines and thus transport the light isotopic signal to the bottom. The latter is unlikely to have been the situation in our study areas since the surface water proxies suggest low salinity in these intervals (Jensen et al., 2004; Roncaglia and Kuijpers, 2004). Instead, an increase in the EGC is recorded (Jensen $e t$ al., 2004). We speculate that this could also have increased the thickness of the PW and thus favour an increased mixing of PW into the Atlantic water mass resulting in the lower oxygen isotope values. A stronger and deeper-reaching EGC would be expected also to influence the East Greenland shelf and thus support the idea of general overall freshening in the Atlantic water masses (Jennings et al., 2001).

The interval between 44 and $23 \mathrm{~cm}$ core depth corresponding to $1070 \mathrm{yr} \mathrm{BP}(\mathrm{AD} 885)$ and $715 \mathrm{yr} \mathrm{BP}(\mathrm{AD} 1240)$ is characterized by the sudden presence of $M$. barleeanus. This species can be related to an environment of high fluxes of partly decomposed organic material to the sea floor (Caralp, 1989). A more intensive mixing of the water-column and possible associated increased primary productivity would result in increased food supply to the benthic community. Another indicator for vertical mixing of the water-column in this time interval is the, increase in the relative abundance of $A$. gallowayi and Cibicides spp., which are indicators of environments with a high hydrodynamic energy level. Increased wave and storm activity could produce such conditions. A considerable reduction of the seasonal ice cover as suggested from the dinoflagellates (Roncaglia and Kuijpers, 2004) is in support of increased mixing and wind stress. This interval corresponds to the warm period referred to as 'The Mediaeval Warm Period' (MWP). On the East Greenland coast this period is described as a warm and stable period with less wind compared to the following colder period (Jennings and Weiner, 1996). This would suggest that the lack of sea ice induced by warming could have been an important factor favouring more turbulent conditions in the Igaliku Fjord. However, during the period of enhanced mixing the record shows a continuously increasing energy level, peaking just before a marked fauna change. Under mainly icefree conditions, such a trend can only be explained by increasing wind stress and associated wave action. This is supported by observations on land showing enhanced erosion and deposition of aeolian sediments in the time interval of the Norse settlement (Vebæk, 1992). It is worth noting that these features have been believed to be mainly due to increased erosion caused by Norse land use (Jacobsen, 1991; Sandgren and Fredskild, 1991). Support for a large-scale change in the wind regime is provided, however, by studies in eastern Canada (Kasper and Allard, 2001). These report intermittent aeolian episodes characterizing the climate in this region during the interval $c$. AD 850 to 1370 .

The foraminiferal fauna reveals a two-step transition towards the peak cooling conditions reaching to a stable stratified watercolumn, around AD 1760. The disappearance of $M$. barleeanus and decrease in current/high-energy indicator species together with a marked increase in $C$. neoteretis indicate less wind forcing and increasing stratification. In our core record the first cooling step culminates AD 1405 (i.e., $17 \mathrm{~cm}$ core depth) and can be correlated to a cooling signal recorded off the East Greenland coast previously referred to as the onset of the LIA (Jennings and Weiner, 1996). They date the culmination of the cooling event to AD 1370 , but given the error of the dating these ages are considered corre- 
sponding. Moreover, these dates also correspond to the time (AD 1350-1400) of significant cooling in the Canadian high Arctic (Koerner and Fischer, 1990).

A short climatic amelioration punctating the cooling trend is suggested around $14 \mathrm{~cm}$ core depth (i.e., AD 1520) with less stratification (decrease in percentage of $C$. neoteretis) and increased mixing (increase in percentage of A. gallowayi). This short episode suggests that the transition from the 'warm' to the cold state was stepwise and not a gradual climatic deterioration. A similar pattern is found further north along the East Greenland coast with temporary warming here dated at around AD 1470 (Jennings and Weiner, 1996). Again, the age difference is within the one-sigma error of the dates and thus these climate signals can be considered to be coeval, indicating large-scale circulation changes. Written records of extensive sea-ice distribution between Greenland and Iceland during this time also suggest that the marine environment experienced intensive cooling (Ogilvie, 1991). However, this climate signal appears to be characteristic of the marine record as the high-altitude ice-core data suggest a more gradual transition towards the peak cold conditions (Dahl-Jensen et al., 1998).

It is stressed that the time resolution of our record does not allow for any conclusion regarding climatic variability within the cold LIA as suggested from other studies in both the marine (Jennings and Weiner, 1996) and ice-core records (Dahl-Jensen et al., 1998).

The clear correspondence between the magnetic susceptibility values and the percentage of the $C$. neoteretis suggest that in this area the magnetic susceptibility profile can be use as a proxy for the influence of subsurface Atlantic water masses and conditions of stable stratification, at least during the last 3000 years. This may be due to through transport of material from offshore, either by Atlantic water masses or by the EGC, found to be more active at times of stable stratification. Alternatively, dilution by material of relatively low magnetic susceptibility of more local origin during periods of increased mixing may explain such a trend. In the latter case, when wind force is thought to be stronger, aeolian deposition could play a role.

\section{Implications for the Norse settlement}

The Norse settled in South Greenland at AD 985 (corresponding to $c .40 \mathrm{~cm}$ core depth in core PO 243-451). According to the palaeohydrographic interpretation of the outer Igaliku Fjord environment, this was a period with a relatively warm climate in terms of surface water temperature, although with increasing wind stress peaking towards the end of the MWP (this study; Jensen et al., 2004; Roncaglia and Kuijpers, 2004). This is in support of findings of an aeolian series of sand deposits accumulated during the final part of the settlement (Jacobsen, 1991). Evidence of episodes of markedly increased atmospheric circulation is also found in east Canada (Kasper and Allard, 2001). Thus, an important conclusion is that enhanced aeolian deposition in the settlement areas could largely be due to regionally intensified atmospheric circulation, and not only due to increased local erosion by Norse land use as suggested by, for example, Jacobsen (1991) and Sandgren and Fredskild (1991).

Based on the presence of $M$. barleeanus during the MWP, it is suggested that the surface productivity in the fjord has been high and thus could have provided a good supply of marine food for the Norse people. Archaeological studies of skeleton remains of the Norse (Arneborg et al., 1999) have demonstrated a marked change in food sources during the Norse settlement period. Originally, $20 \%$ of the food originated from marine sources, whereas at the final stage $80 \%$ of the food had a marine source. From our study we may conclude, that, apart from the possible negative effect of climatic deterioration on Norse land use, this change to some extent thus may also be attributed to an increased potential of marine food, particularly during later stages, when windinduced surface water mixing was at a maximum. The increased wind activity may also explain why the Norse did not build an economy around intensive fishing in the fjords; given the few and valuable small boats they had, it would be very risky. Fishing requires not only more time at sea, with more day-to-day damage to the boats, but also more exposure to storms and hazards than the more intensive seal hunting.

Historical documents on Iceland report the presence of the Norse in South Greenland for the last time in AD 1408, after which we lack any further information about what happened to these people. As outlined above, the first cooling stage recorded in the fjord is dated at $c$. AD 1405, coinciding with the last report of the Norse presence in the area. This coincides with an unprecedented influx of (ice-loaded) EGC water masses into the innermost parts of Igaliku Fjord (Jensen et al., 2004), where the bishop seat of Gardar, a major cultural centre of the Eastern Settlement, was located. Shortly after, i.e., around AD 1450, the climate further deteriorated with further increasing stratification of the water-column associated with stronger advection of (iceloaded) EGC water masses. This suggests an increase of the ice season and a decrease of primary production and marine food supply. This could also have had a dramatic influence on the local seal population and thus the feeding basis for the Norse population (see also Jensen et al., 2004).

Finally, indications have been found for a relative fast subsidence (up to $3 \mathrm{~m} / 1000$ years) of this part of Greenland during the past 3000 years, leading to flooding of lowlands that formed important areas for Norse land use around the fjords (Kuijpers et al., 1998). Thus, it can be concluded that climatic and hydrographic changes in the area of the Eastern Settlement were significant in the crucial period when the Norse disappeared. This may be in support of the view that environmental changes were an important factor contributing to the loss of the settlement.

\section{Conclusion}

The record of benthic foraminifera fauna changes during the last 3200 cal. yr BP have shown that the palaeohydrography of the outer part of Igaliku Fjord is closely linked to the variability of North Atlantic open-ocean circulation. Thus, the last three major Holocene cooling events with increased ice-rafting in the North Atlantic are reflected in the foraminifera faunas as periods with a strongly stratified water-column and Atlantic subsurface water masses prevailing in the bottom-water layer of the outer Igaliku Fjord.

The 'Mediaeval Warm Period' (MWP) was characterized by enhanced mixing of the water-column. In the course of this period, the hydrodynamic energy level in the fjord, and thus the wind stress, is concluded to have increased. In addition, the transition from the MWP towards the 'Little Ice Age' (LIA) is shown to have been stepwise with a short climatic amelioration punctuating the general cooling trend.

\section{Acknowledgements}

The study has been funded by the Danish Natural Science Research Council (grant 9701901, A. Kuijpers et al.) and Danish Research Agency (grant 9802945, A. Kuijpers et al.), with further support from the Government of Greenland (grant N. Mikkelsen), the Nordic Arctic Research Programme (grant N. Mikkelsen) and the Geological Survey of Denmark and Greenland. The core was collected during a cruise (No. 243) of R/V Poseidon, Kiel, carried out in 1998 in collaboration with the GEOMAR Research Center for Marine Geosciences (G. Hoffmann), Kiel, and the AlfredWegener-Institute for Polar and Marine Research (J. Thiede), 
Bremerhaven, Germany. The Royal Danish Administration for Navigation and Hydrography is acknowledged for their pre-cruise bathymetric survey of the study area. This work has greatly benefited from inspiring discussions with Karin G. Jensen and Lucia Roncaglia. Finally, we would like to acknowledge the valuable and constructive comments and suggestions from K.L. Knudsen, T.H. McGovern and one anonymous reviewer.

\section{References}

Arneborg, J., Heinemeier, J., Lynnerup, N., Nielsen, H.L., Rud, N. and Sveinbjönsdóttir, Á.E. 1999: Change of diet of the Greenland vikings determined from stable carbon isotope analysis and ${ }^{14} \mathrm{C}$ dating of the bones. Radiocarbon 41, 157-68.

Arz, H.W., Gerhardt, S., Patzold, J. and Rohl, U. 2001: Millennialscale changes of surface- and deep-water flow in the western tropical Atlantic linked to Northern Hemisphere high-latitude climate during the Holocene. Geology 29, 239-42.

Bianchi, G.G. and McCave, I.N. 1999: Holocene periodicity in North Atlantic climate and deep-ocean flow south of Iceland. Nature 397, 515-17. Bond, G., Broecker, W., Johnsen, J., McManus, J., Labeyrie, L., Jouzel, J. and Bonani, G. 1993: Correlations between climate records from North Atlantic sediments and Greenland ice. Nature 365, 143-47. Bond, G., Kromer, B., Beer, J., Muscheler, R., Evans, M.N., Showers, W., Hoffmann, S., Lotti-Bond, R., Hajdas, I. and Bonani, G. 2001: Persistent solar influence on North Atlantic climate during the Holocene. Science 294, 2130-36.

Bond, G., Showers, W., Cheseby, M., Lotti, R., Almasi, P., deMenocal, P., Priore, P., Cullen, H., Hajdas, I. and Bonani, G. 1997: A pervasive millennial-scale cycle in North Atlantic Holocene and Glacial climates. Science 278, 1257-66.

Broecker, 2000: Abrupt climate change: causal constraints provided by the paleoclimate record. Earth-Science Reviews 51, 137-54.

Buch, E. 2000: A monograph on the physical oceanography of the Greenland Waters. Scientific report no. 00-12, Danish Meteorological Institute, Copenhagen, $405 \mathrm{pp}$.

Caralp, M. 1989: Size and morphology of the benthic foraminifer Melonis barleeanum: relationships with marine organic matter. Journal of Foraminiferal Research 19, 235-45.

Dahl-Jensen, D., Mosegaard, K., Gundestrup, N., Clow, G.D., Johnsen, S.J., Hansen, A.W. and Balling, N. 1998: Past temperatures directly from the Greenland Ice Sheet. Science 282, 268-71.

Eiriksson, J., Knudsen, K.L., Haftidason, H. and Heinemeier, J. 2000: Chronology of late Holocene climatic events in the northern North Atlantic based on AMS ${ }^{14} \mathrm{C}$ dates and tephra markers from the volcano Hekla, Iceland, 2000. Journal of Quaternary Science 15, 573-80.

Finsson, H. 1970: Mannfakkun af hallarum. A second annotated edition of Finsson (1796). Reykjavik: Almenna bókafélagid.

Hald, M., and Hagen, S. 1998: Early Preboreal cooling in the Nordic seas region triggered by meltwater. Geology 7, 615-18.

Hald, M. and Korsun, S. 1997: Distribution of modern benthic foraminifera from fjords of Svalbard, European Arctic. Journal of Foraminiferal Research 27, 101-22.

Hald, M. and Steinsund, P.I. 1992: Distribution of surface sediment benthic foraminifera in the southwestern Barent Sea. Journal of Foraminiferal Research 22, 347-62.

Hald, M., Steinsund, P.I., Dokken, T., Korsun, S., Polyak, L. and Aspeli, R. 1994: Recent and Late Quaternary distribution of Elphidium excavatum f. clavatum in Arctic Seas. Cushman Foundation Special Publications 32, 141-53.

Herman, Y., O'Neil, J. and Drake, C.L. 1972: Micropaleontology and paleotemperature of postglacial SW Greenland fjord cores. In Vasari, Y., Hyvärinen, H. and Hicks, S, editors, Climatic changes in Arctic areas during the last ten thousand years, Series A, no. 3, Geological no. 1, University of Oulu, 357-407.

Hoffmann, G., Kuijpers, A. and Thiede, J. 1999: Climate change and the Viking-age fjord environment of the Eastern Settlement, SW Greenland. 'Poseidon' Cruise no. 243 Cruise Report, Reports on Polar Research 331, AlfredWegener-Institute for Polar and Marine Research, Bremerhaven, $34 \mathrm{pp}$.

Hong, Y.T., Jiang, H.B., Liu, T.S., Zhou, L.P., Beer, J., Li, H.D., Leng, X.T., Hong, B. and Qin, X.G. 2000: Response of climate to solar forcing recorded in a 6000 -year $\delta^{18} \mathrm{O}$ time-series of Chinese peat cellulose. The Holocene 10, 1-7.

Horsted, S.A. 1956: Hydrographic-biological investigations of the southwest Greenland prawn grounds. Meddelelser fra Danmarks Fiskeri- og Havundersøgelser, Ny serie 1, 61-116.
Jacobsen, B.H. 1991: Soil resources and soil erosion in the Norse settlement area of Østerbygden in southern Greenland. Acta Borealia 1, 56-68 Jennings, A.E. and Helgadottir, G. 1994: Foraminiferal assemblages from the fjords and shelf of Eastern Greenland. Journal of Foraminiferal Research 24, 123-44.

Jennings, A.E. and Weiner, N.J. 1996: Environmental change in eastern Greenland during the last 1300 years: evidence from foraminifera and lithofacies in Nansen Fjord, $68^{\circ} \mathrm{N}$. The Holocene 6, 179-91.

Jennings, A.E., Hagen, S., Hardardottir, J., Stein, R., Ogilvie, A.E.J. and Jonsdottir, I. 2001: Oceanographic change and terrestrial human impacts in the post AD 1400 sediment record from the southwest Iceland shelf. Climatic Change 48 (Special Issue, The Iceberg in the Mist: Northern Research in Pursuit of 'A Little Ice Age'), 83-100.

Jennings, A.E., Knudsen, K.L., Hald, M., Vigen Hansen, C. and Andrews, J.A. 2002: A mid-Holocene shift in Arctic sea-ice varibility on the East Greenland Shelf. The Holocene 12, 49-58.

Jensen, K.G., Kuijpers, A., Koç, N. and Heinemeier, J. 2004: Diatom evidence of hydrographic changes and ice conditions in Igaliku Fjord, South Greenland, during the past 1500 years. The Holocene 14, 152-64. Jiang, H., Seidenkrantz, M.-S., Knudsen, K.L. and Eiriksson, J. 2002: Late-Holocene summer sea-surface temperatures based on a diatom record from the north Icelandic shelf. The Holocene 12, 137-47.

Johnsen, S., Dahl-Jensen, D., Gundestrup, N., Steffensen, J.P., Clausen, H.B., Miller, H., Masson-Delmotte, V., Sveinbjörndottir, A.E. and White, J. 2001: Oxygen isotope and palaeotemperature records from six Greenland ice-core stations: Camp Century, Dye-3, GRIP, GISP2, Renland and NorthGRIP. Journal of Quaternary Science 16, 299-307.

Kasper, J.N. and Allard, M. 2001: Late-Holocene climatic changes as detected by the growth and decay of ice wedges on the southern shore of Hudson Strait, northern Québec, Canada. The Holocene 11, 563-77.

Keigwin, L.D. and Pickart, R.S. 1999: Slope water current over the Laurentian Fan on interannual to millennial time scales. Science 286, 520-23.

Koerner, R.M. and Fisher, D.A. 1990: A record of Holocene summer climate from a Canadian high-Arctic ice core. Nature 343, 630-31.

Kuijpers, A., Abrahamsen, N., Hoffmann, G., Hübnerbach, V., Konradi, P., Kunzendorf, H., Mikkelsen, N., Thiede, J., Weinrebe, W., Shipboard scientific party of RV Posidon and surveyors of the Royal Danish Administration for Navigation and Hydrography 1998: Climate change and Viking-age fjord environment of the Eastern Settlement, South Greenland. Review of Greenland Activities, Geology of Greenland Survey Bulletin 183, 61-67.

Kunzendorf, H., Emeis, K.-C. and Christiansen, C. 1998: Sedimentation in the central Baltic Sea as viewed by non-destructive Pb-210 dating. Danish Journal of Geography 98, 1-9.

Mackensen, A. 1987: Benthische Foraminiferen auf dem Island-Schottland Rücken: Umwelt-Anzieger an der Grenze zweier ozeanischer Räume. Paläontologische Zeitschrift 61, 149-79.

Madsen, H.B. and Knudsen, K.L. 1994: Recent foraminifera in shelf sediments of the Scoresby Sund fjord, East Greenland. Boreas 23, 495-505. Murray, J.W. 1991: Ecology and palaeoecology of benthic foraminifera. Harlow: Longman, 397 pp.

O'Brian, S.R., Mayewski, P.A., Meeker, L.D., Meese, D.A., Twickler, M.S. and Whitlow, S.I. 1995: Complexity of Holocene climate as reconstructed from a Greenland ice core. Science 270, 1962-64.

Ogilvie, A.E.J. 1991: Climatic changes in Iceland AD 865 to 1598. Acta Archaeologica 61, 233-51.

- 1992: Documentary evidence for changes in the climate of Iceland, AD 1500 to 1800. In Bradley, R.S. and Jones, P.D., editors, Climate since AD 1500, London and New York: Routledge, 92-117.

Roncaglia, L. and Kuijpers, A. 2004: Palynofacies analysis and organicwalled dinoflagellate cysts in late-Holocene sediments from Igaliku Fjord, South Greenland. The Holocene 14, 172-84.

Sandgren, P. and Fredskild, B. 1991: Magnetic measurements recording Late Holocene man-induced erosion in S. Greenland. Boreas 20, 315-31. Sejrup, H.P., Jansen, E., Erlenkeuser, G. and Holtedahl, H. 1984: New faunal and isotopic evidence on the Late Weichselian-Holocene oceanographic changes in the Norwegian Sea. Quaternary Research 21, 74-84. Steinsund, P.I. 1994: Benthic foraminifera in surface sediments of the Barents and Kara Seas: modern and late Quaternary applications. $\mathrm{PhD}$ thesis, Department of Geology, University of Tromsø, $111 \mathrm{pp}$.

Stötter, J., Wastl, M., Caseldine, C. and Häberle, T. 1999: Holocene palaeoclimatic reconstruction in northern Iceland: approaches and results. Quaternary Science Reviews 18, 457-74.

Stuiver, M., Grootes, P.M. and Braziunas, T.F. 1995: The GISP2 $\delta^{18} O$ climate record of the past 16,500 years and the role of the sun, ocean, and volcanoes. Quaternary Research 44, 341-54.

Vebæk, C.L. 1992: Vatnahverfi - an inland district of the Eastern Settlement in Greenland. Meddelelser om Grønland, Man and Society 17, 132 pp. 